\title{
Reflection on Development Process of Chinese Golf
}

\author{
Xueyun Shao \\ Golf College \\ Shenzhen University \\ Shenzhen, China \\ shaoxy@szu.edu.cn
}

\begin{abstract}
Methods of historical, investigation and literature were used in this paper. Four periods were marked off in the China's golf development process, then followed by positive summary and reflection. It not only enriches the research content of the development history of golf in China, but also has a positive meaning for us to better learn from historical experience and lessons, and to plan its future scientifically in the new situation.
\end{abstract}

Keywords-China; golf; development process; summary; reflection

\section{INTRODUCTION}

The modern golf in China was started in 1984 actually, when Zhongshan Hot Spring Golf Club was built and opened to public in Guangdong. China has obtained many successful experiences in the development process of golf and has laid a good foundation for the further development since the last 29 years, but there are a lot of problems also exist at the same time. So, how to summarize the successful experience, solve the existed problems better serve for the development of China golf in future? A systematic study of China's 29 years of golf development needs to be done. Especially facing new opportunities that golf will return to the Olympic family, it is very urgent and necessary to review the development process of golf in China.

\section{THE DEVELOPMENT PROCESS OF GOLF IN CHINA}

A. The initial phase of development: political needs, gradually introduced (1984 -1994)

After reform and opening up, many overseas investors want to invest in China taking advantage of the national policy. China's first golf club-- Zhongshan Hot Spring Golf club was opened in Guangdong on August 24, 1984. Notice on Carry out Golf Courses firstly in Beijing, Hebei, Guangdong and other places was issued by the former National Sports Commission at the same year. Thus, golf is officially launched as a sports game in China. Nevertheless, the initial motivation that golf is introduced in China is to improve the investment environment and to meet the need of the wealthy and highly-paid man investing in China. There was 13 Golf Club opened and put into use in China in 1994. Most of the golf club was distributed in Beijing, Tianjin, Shanghai, Hainan,
Shenzhen Guangdong, Zhuhai and Zhongshan, all of which are economically developed and earlier open areas in China.

China Golf Association, hereinafter referred to as CGA, was established in Beijing in 1985. CGA is the affiliation association of National Sports Federation. It is also the institution representative for the directly single sports management under the management center of the State General Administration of sports. The first Chinese golf team and the first batch of professional golfers appeared in this period, various events began to cut a striking figure. In 1987, golf was performed in Sixth National Games. The new China's first local Golf Association -- Shenzhen Golf association was established during that time. China participated in three Asian Games, i.e. Seoul of South Korea1986, Beijing 1994and Hiroshima of Japan 1990 Asian Games.

Therefore, a large number of foreign capital inflows leads to that improvement of the investment environment have become a kind of cultural needs. Therefore, they have direct reason to build golf courses in the overseas investment intensive areas. The first 10 years is a beginning stage of golf development in new China. Beijing, Hebei, Tianjin, Guangdong, Hainan and other regions have already started golf facilities construction and golf related talent training. Golf sports have played a very positive role in improving the investment environment and showing opening image, and promoting local economic development.

B. Speed up development period: speed up the development by economy driving (1995 -2003)

In today's view, the development trajectory golf in China has a striking similarity with the Chinese most active economy area. More and more people prefer to play golf, some for fitness, while others for entertainment, some for curious, while others for enjoyment. The 2003 SARS also resulted in many people picked up the club and to the course, recognizing fitness value of golf game.

The speed of golf development in this stage began to accelerate. Besides regions such as Beijing, Bohai ring area, the Pearl River Delta and Yangtze River Delta golf also has developed rapidly, areas like Fujian, Yunnan and Hainan began to develop golf facility as well. There were 219 golf clubs in mainland China, including those under construction but not yet completed at the end of 2003. 
The investment structure shows diversify characteristics from the investment developer perspective. In addition to the enterprises from the United States of America, Singapore, Thailand, Malaysia and other countries began to invest in China golf course construction, domestic investors have begun to set foot in the construction of golf course and gradually become the important subject of investment in this stage. In November, 2002, China's first public golf club -- Longgang Public Golf Club was opened, setting up golf sports' positive image of active, civilized, healthy to the public. So that people from all sectors of society have a new understanding of the game of golf. Its business model interprets the popular trend of golf, opens up a new way to promote golf sports in china.

CGA formally applied to join the Asian Pacific Golf Federation and get through successfully in March 1996. CGA formally joined to the International Golf Federation, in 1998. Golf tournament develops towards the diversification trend in this stage. VOLVO China Open, 41st Heineken World Cup Golf Championship, Straits Cup Golf Professional Invitation, BAT China golf Professional League Cup and Yajule Amateur Tour and other events promote golf coaching, culture exchanges and learning.

Under the endeavor of both Shenzhen government and Shenzhen Golf Association, golf management major was opened in Shenzhen Higher Career Technical College in 1995. It transferred to Shenzhen University and Golf College was established in 1997, founded the golf professional higher education in China. The first international exhibition of China -- Beijing International Golf Expo was launched in 2001, providing a platform for the golf industry to communicate, demonstrate and share the most up-to-date information. The $1^{\text {st }}$ National Golf Club Manager's Conference was held in Jiangmen Pukui Golf Club, Guangdong at the same year, aiming to provide another platform for industry management personnel to exchange experience, explore the development way of industry and to seek common development.

In summary, this stage was the speeding up stage in the development process of golf in china. Driven by the economic, not only more and more people went and played golf, golf facility and golf events increased, and related industries developed as well, and began to try in golf professional education.

\section{Limited period of development: policy adjustment, restricting development (2004 -2007)}

Under the constraints of economic development conditions, natural resource and issues existed in business, management of golf club and so on; the state restricts golf development by making corresponding policy. Reviewing the development process of this stage, we can see that the government launched a series of policies and measures limiting the development of golf in China at this stage. The office of the State Council issued Notice on Suspension of New Golf Course in 2004, in which shows that the new golf course construction must be suspended, the built up golf club including golf facilities under construction need to be clean up, and standardize golf club operation. Formulation and promulgation of these documents has great influence on the development of golf in china.

Nevertheless, the development speed of golf club rose instead of dropping, the annual growth rate reached $25 \%$ $30 \%$. Compared with the central policies taking intervention and limited attitude, many local governments expressed neutral attitudes, some even let the development of golf industry in the local economic development planning. Take Zhejiang Province for example, the six departments including Provincial Planning Commission announced Guidance on Building Golf Course modestly in Zhejiang Province, it pointed out that the construction of golf course in Zhejiang Province should moderate, according to the actual situation. The number of golf course should be controlled within 15[1].

Many international well-known events have settled down in China in this stage, European tours such as the popular Masters, BMW Asian open, Johnnie Walker Championship, HSBC Champions and etc.. Holding world famous games and famous players involvement not only greatly expanded the golf game's influence in China, but also made the Chinese professional players get exercised based on the high level of competition learning.

By the end of 2007, the number of opened up golf club in China has reached to around 260. The golf industry and related industries has also been developed rapidly in this stage, the Chinese golf industry value has reached 4.79 billion RMB in 2006[2].

Obviously, the state focused its attention on the industry policy, land policy, the project approval and tax policy and other aspects of golf course construction at this stage. We could infer that the characteristics of policy tended from relaxation towards regulation, limit was greater than encourage, or even banned the golf course construction. However, local government policy had certain difference with the central government policy, makes the development of golf limited. Based on the need of the development of social economy and market, golf facilities and tournament still developed a certain degree.

D. Standardized Development period: leisure time, regulating the development (2008 - )

According to the World Leisure Organization forecast, the GDP per capita of $\$ 2000$ is the threshold of leisure demand growth, which formed the diverse needs and selection of leisure. When GDP per capita reaches $\$ 3000$, leisure and holiday demand will produce popularly. Leisure has become indispensable to people's life When GDP per capita break through $\$ 5000$. With the continuous improvement of substance living standards of society members, and the large amplitude free time increasing, our country also proudly walk into the new era of leisure.

Why golf is able to develop in the era of leisure lies in the multiple value of golf can bring people in leisure with expected positive good physical and mental experience. In this sense, golf is not a new form of sport, but the awareness and development of multi-value in the process 
of development of mass sports. In other words, golf is a people-oriented sport.

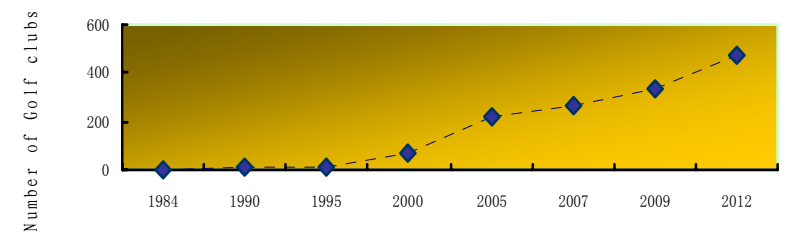

Figure 1. The General TREND of The DeVElopment Process of GOLF CLUBS IN CHINA

International experience shows that golf population growth of a nation and region rate follow one rule roughly, namely that certain economic basis and mental workers considered as the main body of the employment structure is a necessary condition for golf population growth and the golf industry development. Only after a society of middleincome groups, free occupation and white-collar achieving a certain proportion, golf will possibly get developed rapidly. The total number of China's golf facilities has reached to 477 at the end of 2012. The general trend of the development process of golf clubs in China is shown in Fig. 1. According to the national economic development strategy, Chinese economy will maintain high speed growth every year before 2020. Development of golf sports in China still has great potential in $21^{\text {st }}$ century.

\section{SUMMARY ON DEVELOPMENT PROCESS OF GOLF IN} CHINA

\section{A. Different stages of the development process of golf with different purposes in China}

People at different times with different environment and position see different sides of golf, leading to different understanding, views and the trend towards golf. From the fact of golf development in China can be seen that the purpose of development of golf in China in different stages is not the same. The government introduces golf sport for investment purposes initially. Golf course construction is considered as the base to attract foreign businessman and image project construction, in order to promote local economy development.

It is difficult for investors to profit only from golf facility investment, that's why golf and real estate are bounded together in marketing. When luxury villa attached themselves to the people's so-called of aristocratic golf, price immediately doubles. In the face of such huge profits, investors used various means to construct course and villas, leading to the game of golf be given to reveal the identity, wealth, position of reference, especially the media exaggerated golf as sport of the rich and lead the public have offensive, conflicting emotions. Golf was deemed as a high consumption of entertainment and its popular feature was neglected, hindering the public participation and popularization.

When the unexpectedly SARS period comes in 2003, people find themselves have no place to go because populated place was filled with danger, indoor sports went into the trough, and the open golf course became the best place to resist $S A R S$, Golf has become people's preferred fitness and exercise game, enable people to know the value of golf. Despite the approval and construction of golf course was restricted by government, people's lifestyle changed with factors such as the development of society and the leisure time increased, the consumption structure changed from survival consumption to the enjoyment of consumption. More and more people tend to rely on the rich cultural connotation of golf to improve health, to experience leisure and to meet their own needs. People came to realize that golf is just a form of sport

\section{B. The development of golf in China influenced by social economy, cultural factors}

China's reform and opening up frontier is the starting point for the development of golf in China, and golf development often provides power for the development of city. Analysis of the macroeconomic situation shows that the main obstacle of China's economic development has been transferred from production to circulation and consumption fields, difficult balance between supply and demand has been changed from the supply side to demand side. Better areas of China golf development relative concentrates on three areas of the Pearl River Delta, Yangtze River Delta and Beijing-Tianjin Bohai ring. Our country average per capita GDP has exceeded 3000 US dollars in 2008, but China's current per capita GDP level equals to the historical period in middle of $20^{\text {th }}$ century of Europe and the United States from the international comparative perspective. Significant features of this period are: leisure policy government guidance stage, Sports for all has become the leading idea, sports population grows fast, leisure sports become people's common practice[3].

Throughout the 29 years of the development process, we can see China's achievements in the sport of golf include that golf course construction has been rapidly developed, golf population has increased significantly, a lot top golf tournaments are introduced, sports performance is significantly improved, golf media also develops a lot, golf education plays its important role in talent training, golf manufacturing industry achieves a lot, golf industry gradually become scale. But influenced by social economy and culture, the development of golf in China has achieved great achievement, the road of development still fills with difficult.

\section{The development of golf in China lacks of industrial planning and detailed and clear industry specifications}

From the beginning until now, the policy of the country experienced from the change of support to limitation and to restriction. On the whole, a very important reason is the lack of detailed and clear industrial planning, and the lack of industry standards. Golf belongs to entertainment industry in the nation's industry division, and about $20 \%$ high taxes is levied, directly leading to a high starting point of golf club operation cost. The word 
entertainment misleads ordinary people to a large extent that golf is not a form of sport. The government has not play a good role of guiding and supervising the benign development of the golf yet.

There always a universal process from only a few people access to it to widely spread, when the economic conditions and market environment for the development of a new project mature. In 2009, Golf was voted to return to the Olympic Games successfully. We need to prepare for 2016 Rio de Janeiro Olympic Games, in other words, we need to show our strength and competitive sports level in the international arena. So here comes the difficult problem that how to select and train talents in the framework of competitive sports and to improve the technical level of golf.

Golf is the most individualistic sport in the world. It is a very good method to training athletes from national level, especially in the status that domestic golf schools are not in a high level, there not so many of golf coaches and golf facilities. Establishment of national golf team is the current approach preparing for the two consecutive Asian Games. Zhang Xiaoning, director of the State General Administration of sports management center, executive vice chairman and the Secretary-General of China Golf Association, said that the current level of Chinese golf are not first-class level even in Asia, and this situation must be changed as soon as possible. The formation of the national team is to use the advantages of system, training scientifically and systematically, exploring a new road with Chinese characteristics, to improve the level of sports[4].

\section{REFLECTIONS ON THE DEVELOPMENT OF GOLF IN CHINA}

\section{A. Taking history as a mirror, drawing historical experiences and lessons of the development of golf in China}

History is a mirror. It is not only to show us achievement, more important is the experience and lessons. Golf has its special historical background in China, namely the original intention of China to introduce golf is to attract foreign investment, and in other words, it is constructed from the perspective of economic development with foreign investors for their leisure domestic life and business communication. All of these make golf begin its development without athletic sport and a foundation of popular fitness, neglecting education objective. As it is stated above, Chinese 29 years of golf development road map can be depicted as follows:
B. Backing with our country' economic development, recall support from government and public

The development of the world golf trajectory (Fig. 3)

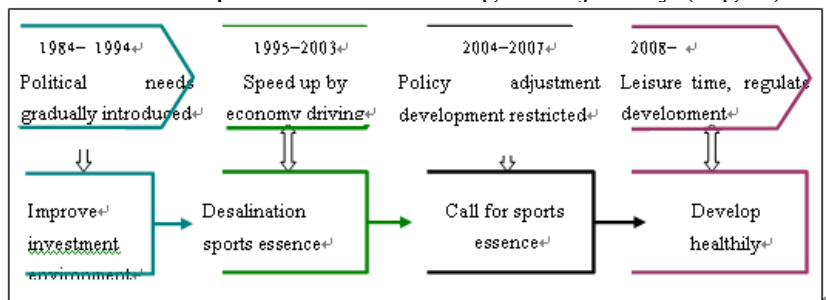

Figure 2. 29 years of golf development road map in China

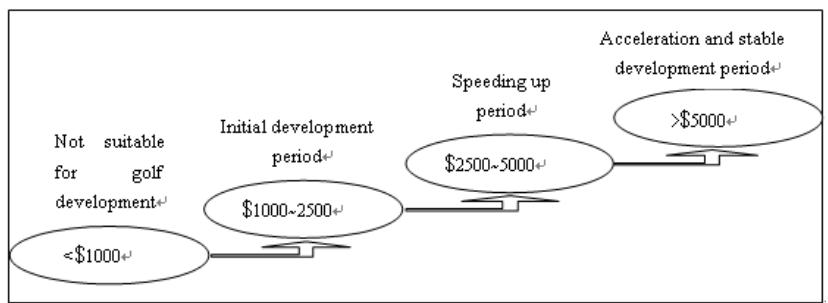

Figure 3. RELATIONSHIP MAP BETWEEN NATIONAL PER CAPITA GDP AND GOLF DEVELOPMENT

shows that when a country's per capita GDP below $\$ 1000$, it is not suitable for golf sports. When it reaches $\$ 1000$, golf enters into the initial development period. When the per capita GDP reached \$2500, golf development will go into the speeding up period with the rapid increase of golf facility demanding. When per capita GDP is more than $\$ 5000$, golf development will be into the acceleration and stable development stage.

In addition to the internal driving force of economic development, the development of golf is also influenced by the government's macroeconomic policies. Policies such as the implementation of paid leave system, sports leisure education practice, approval and construction system golf facilities project, support and foster of golf industry and related industries policy need to formulate and perfect. Combining with the development experience of foreign golf, research predicts that number of golf course in China can reach about 1480 in 2015[5].

\section{Clear positioning, standardize development and optimize structure}

Lack of golf education and the special background of issues in China make the golf culture and philosophy in China has not been very good spread yet. It is regarded as the product of high consumption, resulting in most of the golf participator in our country is still dominated by the upper middle class consumer groups at present. Only one public golf club here in China. People yearned to consume golf not for the purpose of golf culture, but to show their identity and status symbol. People considered that golf was a kind of identity. The reality golf consumption crowd in China is concentrated in the rich people. Many people plays golf showing of wealth performance, and give the public an unfair impression. Some executives of state- 
owned enterprises and government officials use their power to consumption golf leading the masses have negative opinions about them. In addition, because of China, or the characteristics of Asians, the golf course is usually known as the casino. All of these against golf culture and etiquette, no wonder golf in China left the noble sports impression to the people at the present stage, making some people appear exclusion and hatred.

Facing with the achievements and contributions of golf, future development of it should be clearly positioned and fully affirmed. We should look carefully into its positive effect on economy, formulating industry policy, industry standards and related regulations to adapt the development status and golf sports in China, leading it onto the healthy road of development.

\section{CONCLUSIONS}

Originated in people's production and life, golf has a long history and profound cultural connotation. It has very high fitness, economic and social value. More and more people's attention is attracted by its unique culture. From the development of golf in China, we can infer that, influenced by the social economy and culture, although the development of golf in China has achieved great achievement, it is still very difficult to develop in the future. The future of China's golf development should pay attention to the spread of golf spirit, golf culture promotion, recall golf as the nature of sports to play its due role.

\section{ACKNOWLEDGMENT}

This paper is financially supported by National Social Science Foundation of China (Grant No. 13CTY034), and Foundation for Distinguished Young Talents in Higher Education of Guangdong, China (Grant No. 2012WYM_0117).

\section{CORRESPONDING AUTHOR}

Xueyun Shao, shaoxy@szu.edu.cn, 86+13510198798.

\section{REFERENCES}

[1] Hangzhou Municipal Development and Reform Committee office, "Six departments of Provincial Planning Committee put forward guiding opinions on modest Golf Course construction in Zhejiang Province”,2003.

[2] Chinanews.com, "Golf industry will enter a peak period of development, output value of this year will exceeding sixty billion”,2009.

[3] H. Zhu, "Research on China city leisure sports service system," in PhD thesis of Beijing Sport University, 2006, pp.79.

[4] J. Zh, "Golf also has a national team," in The first financial daily,2006.

[5] X. Yang, "Research on China golf club development strategy," in $\mathrm{PhD}$ thesis of Jinan University, 2004, pp.67. 